\title{
Facilitative and Mandatory Rules in the Corporation Law(s) of the United States
}

\section{INTRODUCTION}

"The longstanding mandatory nature of American corporate law. . can no longer be accepted without question and reflection."1 With this introduction to a now-classic debate on contractual freedom in corporate law, the influence of modern economic views on the nature of the firm, launched 60 years earlier by Coase, ${ }^{2}$ reached mainstream corporate law discourse in the United States. From the perspective of the positive law, however, this was hardly a revolutionary view. State codes had supported a facilitative rather than a regulatory treatment of corporations - whether that facilitation was mandatory or not - since the enactment of New Jersey's corporation code in 1875. ${ }^{3}$ It follows that the U.S. discussion of the issue of mandatory versus suppletive ${ }^{4}$ or optional rules is in one sense of limited comparative utility: after all, the less onerous a nominally mandatory rule, the less relevant the debate. As will become clear below, that may be the most important point to take away from a discussion of U.S. law.

Richard M. Buxbaum is Professor of Law, University of California, Berkeley

1. Bebchuk, "Foreword - The Debate on Contractual Freedom in Corporate Law," 89 Colum. L. Rev. 1395, 1398 (1989). See also Bebchuk, "Limiting Contractual Freedom in Corporate Law: The Desirable Constraints on Charter Amendments," 102 Harv. L. Rev. 1820 (1989).

2. Coase, "The Nature of the Firm," 4 Economica (n.s.)386 (1937). The standard modern citations proclaiming the "nexus of contracts" economic philosophy are to $\mathrm{Al}$ chian \& Demsetz, "Production, Information Costs, and Economic Organization," 62 Am. Econ. Rev. 777 (1972) and Jensen \& Meckling, "Theory of the Firm: Managerial Behavior, Agency Costs and Ownership Structure," 3 J. Fin. Econ. 305 (1976).

3. For an almost contemporaneous analysis, by an authoritative source, see Keasby, "New Jersey and the Great Corporations," 13 Harv. L. Rev. 198 (1899). This enabling philosophy, generated by forces described in the immediately following text, was much studied throughout the following period; see, e.g., John Cadman, The Corporation in New Jersey (1949).

4. A variety of adjectives has been used to describe rules that are not mandatory. "Suppletive" is one of them; "optional" another; "default" and "standard contract" yet others. "Facilitative" is less useful, since an entire code may be facilitative - and U.S. codes are - yet contain mandatory elements. 


\section{History}

Five related and reciprocally influential phenomena go far to explain the unique path United States corporation law took from the beginning of the Gründerjahre. ${ }^{5}$ A brief review of these is essential to an understanding of the present situation, in particular to its comparative relevance elsewhere. First, for political and historically contingent reasons corporation law is state law, not federal law, though in Constitutional terms it could be otherwise. ${ }^{6}$ Second, the geographic and demographic particularities bundled together under the reductionist historical rubric of American exceptionalism led to a narrow definition of state corporation law, a definition that limited its concern to the relationship of owners and managers and excluded from its purview the interests of employees and creditors let alone more general classes. ${ }^{7}$ Third, in partial consequence of the first two phenomena, such "third-party" interests as did within the political system deserve or receive attention did so largely at the federal level, relieving state corporation law from otherwise unavoidable pressures to reconsider this narrow focus. ${ }^{8}$ Fourth, again for historical reasons, statutory corporation law in the U.S. always has been unitary law, applying the same rules to the single-owner or family corporation that it applies to the large, publicly held one. ${ }^{9}$ Finally, the historically and judicially determined traditional American rule of the con-

5. To the significance of this post-Civil War period as a watershed for the legal treatment of corporations, see generally N. Horn \& J. Kocka, (eds.), Recht und Entwicklung der Großunternehmen im 19. und frühen 20. Jahrhundert - Law and the Formation of the Big Enterprises in the $19^{\text {th }}$ and Early $20^{\text {th }}$ Centuries (1979).

6 . Indeed, around the turn of the previous century there was a substantial movement towards federal corporation law. See for a contemporaneous overview Roland Heisler, Federal Incorporation (1913); for a more current though brief analysis, see Alfred Conard, Corporations in Perspective 6f., 70f. (1976); and for a more detailed review, see Jennings, "Federalization of Corporate Law: Part Way or All the Way," 31 Bus. Law. 991 (1976).

7. The so-called populist demand for general incorporation law to avoid the inequities popularly associated with the need for special legislation for each incorporation, culminating in the Jacksonian Period in the pioneering 1837 general incorporation statute of Connecticut, also can be subsumed under this heading. See generally $2 \mathrm{~J}$. Davis, Essays in the Earlier History of American Corporations (1917), chs. 3 and 4.

8. Indeed, to the degree that the existence of the Commerce Clause of the U.S. Constitution, even when unexercised in the form of affirmative federal legislation, could be used to preclude mandatory (and thus potentially restrictive) state law, these interests could to that extent only be given legislative expression at the federal level. See generally Richard M. Buxbaum \& Klaus J. Hopt, Legal Harmonization and the Business Enterprise 46ff (1988).

9. The relatively recent adoption of a few provisions authorizing contractual (i.e., unanimous) variation of some otherwise mandatory rules, generally but misleadingly called close corporation statutes, is another matter. These are not, however, complete codes. They originally were designed to permit decisions otherwise assigned to the board of directors to be made by shareholders overturning judicial decisions that had invalidated efforts of that sort because they "sterilized" the board of directors. Of course, to the extent some of these "codes" permit a larger range of variant options they indirectly have created a dual statutory regime in the field relevant to this discussion. See the treatment of that issue below. 
flict of laws - that these so-defined internal affairs of the corporation were governed by the law of the state of incorporation ${ }^{10}$ - generated an early competition to enact enabling corporation codes with a minimum of regulatory apparatus, a competition that was not feasible for those European jurisdictions that based their private international law rule on the concept of the siegge social. ${ }^{11}$

The emerging though still contested legal-economic philosophy argues for both a contractarian view of (even) the publicly owned corporation and for a minimally mandatory and maximally facilitative approach to its governing law. ${ }^{12}$ One of the more prominent presentations of this view combines these two points as follows:

"The corporation is a complex set of explicit and implicit contracts, and corporate law enables the participants to select the optimal arrangement for the many different sets of risks and opportunities that are available in a large economy. No one set of terms will be best for all; hence the 'enabling' structure of corporate law. ..."

"One natural question after all this. . is: why law? Why not just abolish corporate law and let people negotiate whatever contracts they please? The short but not entirely satisfactory answer is that corporate law is a set of terms available off-the-rack so that participants in corporate ventures can save the cost of contracting." 13

The principal argument in favor of limiting the reach of this approach is composed of a mixture of concerns, principally the concern that investors may be relatively uninformed and the concern that corporate "contracts" are unique in their combination of longevity and discretion. ${ }^{14}$ An institutional answer to these contrasting positions emphasizes the historically well-embedded role of the courts as arbiters of these issues on a case-by-case level. ${ }^{15}$

One might argue that the preference for a contractarian view of corporation law, especially including its normative aims, is an epi-

10. See generally Restatement Second, Conflicts of. Laws, Sections 296-310 (1971).

11. See generally Richard M. Buxbaum \& Klaus J. Hopt, Legal Harmonization and the Business Enterprise (1988), at $62 \mathrm{ff}$.

12. The second point is non-controversial, and in a sense arises necessarily from the historical and institutional premises already stated. For a good if slightly dated "mainstream" demonstration of this point, see Henry Ballantine, Corporations 41ff. (rev. ed. 1946). The first point, of course, is more controversial, as the varying contributions to the seminal 1989 Columbia Law School Symposium (infra n. 16) demonstrate.

13. Easterbrook \& Fischel, "The Corporate Contract," 89 Colum. L. Rev. 1416, (1989).

14. For a brief overview of these and other concerns, see Gordon, "The Mandatory Structure of Corporate Law," 89 Colum. L. Rev. 1549 (1989).

15. See especially Coffee, "The Mandatory/Enabling Balance in Corporate Law: An Essay on the Judicial Role," 89 Colum. L. Rev. 1618 (1989). 
phenomenon, derived from and limited to these particularities of the United States scene. ${ }^{16}$ On the other hand, one might view the contractarian argument as descriptive and predictive: It is the positive law that is the epiphenomenon, one that has evolved towards its facilitative form because, given the underlying economic realities, it had to. In this sense, the question worth comparative reflection is a mixed one of fact and theory: Are markets/economies of other major states/regions evolving towards the American one in the objective terms of size and wealth; if so, can any economy compete without a legal regime giving its corporations the same benefits? ${ }^{17}$

\section{Classification}

\section{A. The Basic Definitional Problem: Who Is Protected By Mandatory Rules?}

Two categories of mandatory rules should be noted. The first consists of those few rules still found in Corporation Codes that protect third parties, principally those involving their protection in the context of two transaction sets: minimum capitalization, and distribution of assets by way of dividends or in liquidation. The first of these two no longer is interesting in the U.S. code context. Because of its unitary nature, requiring its application to small/privately held as well as large/publicly held firms, the typical state statute has no minimum capital requirement. Such minimal creditor protection as a minimal capitalization requirement might provide (as compared with that available by means of contractual protection) is applied retrospectively through the litigation-related doctrines of the disregard of the corporate entity. ${ }^{18}$ The second of this creditor-protection set, that protecting against excessive asset distributions, continues to have more bite; ${ }^{19}$ indeed, given its role in bankruptcy and corporate reor-

16. This has not, however, kept American authors from challenging European mandatory corporation-law provisions, such as the requirement of significant minimum capitalization. See, e.g., Enriques \& Macey, "Creditors Versus Capital Formation: The Case Against the European Legal Capital Rules," 86 Cornell L. Rev. 1165 (2001) (to be fair, Professor Enriques is Italian).

17. See Coffee, "The Future As History: The Prospects for Global Convergance in Corporate Governance and Its Implications," $93 \mathrm{Nw}$. U. L. Rev. 641 (1999).

18. To this issue, including its comparative context, see Buxbaum, "The Formation of Marketable Share Companies," in Alfred F. Conard, (ed.), Business and Private Organizations, XIII International Encyclopedia of Comparative Law (fasc. ed. 1972).

19. On the different approaches to the potential conflict between state companylaw norms concerning distributions to shareholders (usually somewhat protective of the latter) and state-level creditors' remedies norms (less so), not to mention federal norms, see Model Business Corporation Act Annotated, Commentary to Section 6.40: "'[I]t was not thought necessary to make the tests of section 6.40 identical to the tests for insolvency under these various [federal Bankruptcy Act and state fraudulent conveyancel statutes." For analysis, see Kummert, "State Statutory Restrictions on Financial Distributions by Corporations to Stockholders - Part II," 59 Wash. L. Rev. 185 (1985). A paradigmatic case on this ranking conflict is Reilly v. Segert, 201 N.E.2d 444 (IIl. 1964). 
ganization proceedings, where it reemerges in doctrines of fraudulent conveyances, unlawful preferences, and equitable subordination, it has a major role to play in creditor protection..$^{20}$

The second category of mandatory rules focuses on the protection of non-controlling shareholders. Here, too, two sets of rules are found. The first set is structural; it concerns the division of powers between the shareholders and the management (whether at the Board of Directors or at the Executive Officer level). A classic example is the reservation of certain major, structural decisions - mergers, sale of all or substantially all assets, dissolution and liquidation - to the shareholders, even if in practice these may be little more than ratificatory acts all but forced upon the shareholders by the preliminary acts of the directors or officers. The second set is behavioral; it concerns the duty of directors and officers to avoid conflicts of interests and gross imprudence. ${ }^{21}$ A classic example is the statutory control of decisions by directors that involve corporate transactions with themselves or some of their number.

This last point also calls attention to what may not be a uniquely American issue but is more apparent there than in other similarly evolved economies. Because of their transaction-specific nature, questions of managerial behavior in the spheres of the duties of prudence and loyalty were handled through the classic common law, with no statutory framework whatsoever, well into the second half of the $20^{\text {th }}$ century. The skeletal codifications of these common-law norms, when they finally did arrive, not only were highly abstract but were focused more on identifying the decisional processes that would pass muster than on substantive norms. ${ }^{22}$ The consequence I draw

20. See to this aspect Clark, "The Duties of the Corporate Debtor to Its Creditors," 90 Harv. L. Rev. 505 (1977). The most interesting and debatable aspect of this subject lies in the bankruptcy context: the right of the trustee to pursue owners/affiliates of the corporate debtor not only to recover unlawful transfers but to charge them with the corporation's debts on alter-ego grounds. For a sampling of cases and commentaries, see S.I. Acquisition, Inc. v. Eastway Delivery Service, 817 F.2d 1142 ( $5^{\text {th }}$ Cir. 1987); St. Paul Fire and Marine Insurance Company v. Pepsico, Inc., 884 F.2d 688 (2d Cir. 1989); Schimmelpenninck v. Byrne, 183 F.3d 347 ( $5^{\text {th }}$ Cir. 1999) (separately interesting in involving proceedings ancillary to a foreign bankruptcy administration); Epling, "Trustee's Standing to Sue in Alter Ego or Other Damage Remedy Actions," 6 Bankr. Dev. J. 191 (1989); Alexander, "Unlimited Shareholder Liability Through a Procedural Lens," 106 Harv. L. Reu. 387 (1992), esp. at $415 \mathrm{ff}$.

21. Imprudence or gross negligence no longer is a ground for significant complaint. Most state statutes now permit amendment of articles of incorporation to limit or eliminate the personal liability of directors for otherwise actionable breaches of the duty of care. The prototype was Delaware General Corporation Law Section 102(b)(7). According to Robert Hamilton, Corporations, Including Partnerships and Limited Liability Corporations 780 ( $7^{\text {th }}$ ed. 2001), 43 states now have similar provisions.

22. See Bulbulia \& Pinto, "Statutory Responses to Interested Directors' Transactions: A Watering Down of Fiduciary Standards?," 53 Notre Dame Law. 201 (1977); more generally and with a wider historical sweep, Marsh, "Are Directors Trustees? Conflicts of Interest and Corporate Morality," 22 Bus. Law. 35 (1966). 
from this history, however, at least at this stage, is not that all statutory efforts to provide general rules for the unavoidable multitudes of particularized events are insufficient by nature. It is, rather, that the judiciary by nature - that is, in the context of litigation about specific transactions - is bound to be skeptical of managerial efforts to avoid condemnation of demonstrably bad outcomes merely by reference to good processes.

\section{B. The Basic Definitional Problem: What Is "Mandatory"?}

The distinction between a mandatory and a non-mandatory ("suppletive"; "optional"; "default"; "standard contract") rule is not as obvious as it may seem to be. Certainly a statutory norm that may not be changed is mandatory. But it is misleading to label all other norms as "optional" if by that is meant that such norms may dilute or diminish the rights and protections of shareholders and increase the powers and immunities of directors and officers. ${ }^{23}$ First of all, a statutory provision may permit a higher level of protection of shareholders by appropriate agreement and adoption (in the articles of incorporation or bylaws): An appropriately adopted variant provision that does not allow officers and directors of a specific corporation to be indemnified to the extent permitted by the default rule would be an example, and there are many other examples. Second, a statutory provision may only bear on the decisions of shareholders and have no relevance to the rights of directors: A variant provision adopting a higher majority voting requirement for all or specified shareholder decisions, beyond the bare majority vote requirement of the default rule, would be an example; again, a number of similar examples may be found. Perhaps the single most important and most frequently found example in this reverse category is a variant provision shifting decisional power from the directors to the shareholders. This is by no means limited to the field of close corporations, even if for obvious reasons it is the harder to implement the larger the number of shareholders.

All this said, of course, it is important to recognize that the debate over the mandatory or optional nature of statutory corporation law has to do with the ability of shareholders to waive the protection of rules governing the behavior of their director or executive agents, and with their analogous ability to waive their right to take at least some structural decisions and instead to permit these agents to take them.

Closely related, though beyond the scope of this report, is the trend towards increasing the barriers to the (typically derivative) litigation that would enforce what remains of these substantive rules. See the full discussion in American Law Institute, 2 Restatement of Corporate Governance Part VII Chapter 1 (994).

23. Since the category of rules intended to protect creditors and third parties typically are mandatory, $I$ ignore them in this discussion. 


\section{A Baseline of Mandatory Rules}

A theoretical effort to identify those elements of corporation law that should remain mandatory is that of Eisenberg, ${ }^{24}$ who after identifying those behavioral rules (duty of care, duty of loyalty) that should be mandatory, adds to this mandatory category what he calls structural rules that "double as fiduciary rules" because they address positional (principal-agent) conflicts:

"These core structural rules fall into several categories. One set of mandatory structural rules should provide for the appointment and monitoring of senior executives by a governing organ (that is, a board of directors) that is elected by shareholders for a limited term of office, a majority of which is composed of members who are independent of the senior executives. A second set should require periodic disclosure of detailed financial data and information concerning material business and legal developments and should provide for institutional mechanisms to ensure that the financial data is reliable. A third set should concern the approval of, and dissent from, transactions that tend to raise positional conflicts. In general, shareholder approval should be required for any transaction in control to which the corporation is a party. ... [including the right of dissenting shareholders to be bought out at fair value]. A final set of mandatory structural rules should protect the integrity of shareholder voting." 25

A different baseline, one derived from positive statutory law, may indirectly be derived from the effort of a state to insist on the application of its local corporation law to corporations incorporated elsewhere; that is, in a partial legislative override of the mentioned "internal affairs" principle of the traditional U.S. conflict of laws. Thus, a well-known and much debated provision of the California General Corporation Law $^{26}$ applies to nominally foreign (i.e., out-ofstate) corporations that in functional terms "belong" more to California than to any other state including the state of incorporation the following catalogue of its substantive provisions: ${ }^{27}$

24. Eisenberg, "The Structure of Corporation Law," 89 Colum. L. Rev. 1461 (1989).

25. Id. at $1480 \mathrm{f}$.

26. Section 2115 .

27. This is often called the pseudo-foreign corporation issue, known in Civilian systems largely through the work of Sandrock; see originally Sandrock, "Internationale Probleme multinationaler Korporationen," 18 BerdGesVR 169 (1978), especially at $257 \mathrm{ff}$. "Pseudo-foreign" is not quite correct, however. The statute identifies four factors - property, payroll, sales, and shareholder address - as relevant. If more than $50 \%$ of each is Californian, the provision applies. Thus, a corporation could be significantly "foreign" but still have this law apply. For the sake of comprehensiveness, I should also point out that foreign corporations with shares listed or traded on national exchanges or markets escape this provision (Section 2115 (c)). 
- annual election of directors

- removal of directors without cause or by court proceedings

- filling of director vacancies where less than a majority in office elected by shareholders

- directors' standard of care

- liability of directors for unlawful distributions

- indemnification of directors, officers, and others

- limitations on corporate distributions in cash

- liability of shareholder who receives unlawful distribution

- requirement for annual shareholders' meeting and remedy if same not timely held

- shareholder's right to cumulate votes at any election of directors

- procedures and limits for providing supermajority vote requirements

- limitations on sale of assets

- limitations on mergers

- reorganizations

- dissenters' rights

- records and reports

- action by Attorney General

- rights of inspection

The same California statute, however, allows the agreement of shareholders of a "close corporation" - if unanimous - to deviate from this list as to many of the substantive provisions contained therein; for example, from the procedures for the removal of directors, from the statutory duty of care, from the procedural correction of conflicts of interests, from the provisions for indemnification of directors and officers, from the requirement of cumulative voting, from the supermajority vote requirements, and more. ${ }^{28}$ In other words, the fact that Section 2115 requires the application of its catalogue of provisions in the private-international-law context does not allow the automatic characterization of the list as one of mandatory application in the substantive context.

28. California General Corporation Law Section 300(c). The technical concept of the "statutory close corporation," which enjoys this possibility, is defined principally by the maximum number of shareholders (35) and the requirement that contractual variations from the statutory scheme be unanimously adopted. Id., Sections 158(a) and $300(\mathrm{~b})$. In practice, this means that any California corporation of this size may treat all but a small number of statutory provisions as "standard contract" default rules subject to variation. In some states - Delaware (General Corporation Law Section 342) - the corporation must restrict the free transfer of the shares in order to benefit from this status; in yet others (Model Business Corporation Act Close Corporation Supplement Section 11) this transfer restriction itself is optional. Which of a statute's otherwise mandatory rules may be subject to variation by a close corporation, however, is not clear in most jurisdictions; only California seems to have adopted the described specific "residual mandatory rules" catalogue. 
Both the particular and the general in these two excerpts of course would apply to rules that are enabling as well prohibitory, that bear on rights as well as duties, and that apply to shareholders as well as directors. They need, therefore, to be examined in some detail. Furthermore, that examination itself needs to be preceded by a review of the typical division of powers ${ }^{29}$ among the three decisionmaking organs of the corporation: the organ called shareholders, the organ called the board of directors, and the organ identifiable as the chief executive officer or officers.

\section{The Relation of Power to Adopt and Substance}

The first contextual point concerns the (mandatory) procedural rules involving the adoption of variant provisions that replace the otherwise applicable (optional; i.e., "default") substantive rule. The principal issue here is the distinction between the statut (articles of incorporation; certificate of incorporation; charter) of the corporation and the bylaws of the corporation as to two elements: who may adopt or amend each; and in which document does a particular right or limitation need to be placed in order to be effective. The initial adoption of the articles of incorporation is a function of the incorporators. Their amendment - the more important issue - requires the approval of the shareholders but, paradoxically, only after the board of directors first recommends that course of action to the shareholders; in other words, the shareholders have no right of initiative in this respect. Thus, in all cases of optional (default) provisions in which the alternative needs to be placed in the articles of incorporation, any alternative provision is hostage to the consent of the board of directors to that alternative. ${ }^{30}$

Let us take the example of the statutory rule that the sale of all or substantially all assets shall be effected by simple majority vote of the shareholders. Putting aside the unusual and perhaps infeasible case of an effort to permit a lesser vote by appropriate special rule, it is a given in U.S. law that a higher vote, or a voting requirement even for the sale of less than substantially all assets, would be legal. Because such an original provision or a later-introduced one would require shareholder action, however, it would have to be provided for in the articles of incorporation; a bylaw would not suffice to adopt that variant on the default rule of the statute. In effect, therefore, directorial approval of such a provision (protective of a minority) would be required, because of the directors' role as gatekeepers to the articles of incorporation. This is not particularly problematical in the situa-

29. Whether typical in normative (mandatorily typical!) or descriptive (optionally typical!) terms.

30. Typical is Model Business Corporation Act Section 10.03; see Williams v. Geier, 671 A.2d 1368 (Del. 1996) 
tion in which no structural conflict exists between directors and shareholders, but as the later discussion will show, it is a significant problem in the case of such conflicts (for example, in the adoption of provisions concerning appropriate actions in the face of takeover bids).

The situation is different in the case of bylaws. Shareholders as well as the board of directors have the statutory competence to adopt and amend bylaws; the problem, rather, is whether some provisions (permissible in the abstract as variations on a non-mandatory legal rule) properly may be placed in bylaws at all. This ties to the second contextual point: Does statutory and decisional law require particular variants on the statutory "default" rule to be placed in one or the other document. One minor problem in this regard arises from the fact that bylaws, unlike articles of incorporation, are not public records; this may create problems of notice not only for creditors but for new shareholders. The major problem, however, arises when management challenges the legitimacy of a shareholder-initiated proposal to amend the bylaws to include a provision that, according to management, lies within the latter's exclusive competence as granted by the applicable statute - a competence that, while only based on a "default" rule, would require an amendment of the articles to be so changed. In short, this intertwining of the two contextual issues turns out to mark the central question of a general corporate policy concerning the division of powers between the principal organs of the corporation.

This is indeed a central issue. It overshadows the debate over the mandatory versus optional nature of statutory rules and has been the subject of much recent litigation, not surprisingly in the area of takeover bids. For present purposes it is sufficient to point out that the standard statutory concept that "the business and affairs of the corporation are managed by or under the supervision of the board of directors" has been used, especially by the Delaware courts, to deny to shareholders the right to propose - and procure a shareholder vote on - bylaw provisions that would require shareholder participation in the adoption or employment of particular defensive strategies against hostile takeover bids. ${ }^{31}$ These decisions of course leave open the wholly theoretical possibility that the constitutive document of the corporation - the articles of incorporation - could legitimately so provide, but that is an illusory situation because of the directors' gatekeeper veto over that approach. As a result, a major set of corporation-law rules that in theory are merely optional have in fact been reconstituted as mandatory - unless the board of directors chooses otherwise.

31. See the discussion in Quickturn Design Systems, Inc. v. Mentor Graphics Corporation, 721 Atl.2d 1281 (Del. 1998), though the decision is on another point. 
This point has given rise to a major debate over "opt-in" versus "opt-out" default rules; and, again, the hostile-takeover context provides the pertinent example. A statute might provide that a Board of Directors could adopt certain poison-pill defenses exercisable when a hostile takeover bid is made, though only if the shareholders have voted to grant the directors that power; but allow the opt-in option of having the articles of incorporation specify otherwise (that is, granting this power to the directors in advance and in blank). ${ }^{32}$ While this may seem only a trivial variant on the current situation - after all, the articles of incorporation always could so provide in any event - it has the significant consequence of bypassing the directors' gatekeeper veto power over any amendment of those articles. The directors still may be able to obtain shareholder approval of their recommendation to amend the articles in this direction: the ease with which they do get that approval in other situations, such as amending the articles to permit reincorporation in another state or to eliminate directors' liability for breaches of the duty of care suggests this possibility. ${ }^{33}$ Nonetheless, as shareholders become more focused on the pros and cons of these particular defenses, that acquiescence may become less likely. ${ }^{34}$

So far as the positive law is concerned, however, it continues to hew to default rules maximizing the role of the Board of Directors, and requiring a theoretically available shareholder-power alternative to travel the impassable road of charter amendment. The classic and most important example is the Delaware statutory provision creating the baseline for a target company's position vis-à-vis potential hostile takeover bids and specifying the procedure for its variation by the opt-out process: ${ }^{35}$

“(a) ... [A] corporation shall not engage in any business combination with any interested stockholder for a period of 3 years following the date that such stockholder became an interested stockholder [i.e., obtained at least $15 \%$ of the stock in a first bid] unless

(1) prior to such date the board of directors of the corporation approved ... the transaction. . .or

(2) ... [the bidder obtained $85 \%$ or more of the stock in the first bid], or

32. See the general proposal by Bebchuk and Hamdani, "Optimal Defaults for Corporate Law Evolution," 96 Nw. U. L. Rev. 489 (2002).

33. See, e.g., Romano, "Corporate Governance in the Aftermath of the Insurance Crisis," 39 Emory L.J. 1155, 1157 ff. (1990).

34. See, e.g., the battle described in International Brotherhood of Teamsters $v$. Fleming Companies, 975 Pac.2d 907 (Okla. 1999). This approach also minimizes both the rational-apathy and political/egal-conflict dilemmas that limit the interest and ability of individual and institutional investors respectively in launching proposals to obtain support for shareholder proposals to force an opt-out vote.

35. Section 203, Delaware General Corporation Law (1988). 
(3) . . . [after the first step] the business combination is approved by the board of directors and authorized. . by the affirmative vote of at least $662 / 3 \%$ of the outstanding voting stock which is not owned by the interested stockholder.

"(b) The restrictions contained in this section shall not apply if:

(1) . ...[a director-enacted bylaw opts out of it];

(2) The corporation, by action of its board of directors, adopts an amendment to its bylaws within 90 days of February 29, 1988, expressly electing not to be governed by this section. . .;

(3) The corporation, by action of its stockholders, ${ }^{36}$ adopts an amendment to its certificate of incorporation or bylaws expressly electing not to be governed by this section. . . [under a special rule requiring an absolute majority of outstanding shares being voted in favor]. ...[A]n amendment adopted pursuant to this paragraph shall not be effective until 12 months after the adoption of such amendment. . . [and shall not apply to any takeover transaction commenced in the intervening period]."37

The policy tendency of this statute is clear. Given the wave of Delaware reincorporations that occurred over the past two decades, it has been estimated that $80 \%$ of the business capital of U.S. corporations now is subject to this provision, as compared with $20 \%$ at the beginning of the movement. ${ }^{38}$ No examples of a (director-initiated) opt-out from it have been reported.

\section{The Trend Away from the Mandatory Nature of MaNAgERIAL Duties}

The principal other context within which the question of mandatory rules has recently been discussed is that of specifying corporate agents' duty of loyalty. Understandably, this has been largely an issue of close corporations, and even there of particular types of close corporations. The typical example is an entity that is formed to put passive owners' capital contribution to some tax-efficient use such as investment in real estate. The promoter of the venture also is the person who identifies the potentially attractive assets and

36. This section does not refer to Section $242(\mathrm{~b})(1)$, the statutory requirement that amendments first be approved by the directors and only then recommended to the shareholders for action. Whether this signals an exception to that requirement is unclear.

37. There are other exceptions, principally taking privately held corporations out from the provision. For these, and a general review of the section, see Choper, supra n. 12 , at $1095 \mathrm{ff}$.

38. Id. at 1096. 
through whom they may be purchased. That promoter, as a specialist in this line of business, may be involved in a number of similar ventures, and may be either the agent or even the principal on the other side of the acquisition transactions in many of these ventures. Absent contractual exculpatory provisions built into the articles of incorporation (or into the partnership agreement if a partnership), the duty of loyalty might prevent this promoter's involvement in other ventures or in the transaction with this company.

Two approaches might be, indeed have been, taken to deal with this issue, assuming that the passive investors, ex ante, are comfortable with a variant rule or rules. One is contractual: the range of selfdealing transactions and corporate opportunities this promoter-corporate agent may engage in is set forth in the governing document. That is subject to judicial review of these provisions in case of later dispute, often an intensely factual review and one colored by the (itself largely common-law) default rule concerning loyalty. The other is to create a "softer" statutory form which itself expresses a more or less contrary default rule of limited loyalty duties and would require the clear contractual statement of firmer rules. This is the route that the new forms of general and limited partnership, limited liability partnership, and limited liability company statutes have traveled. A typical example, taken from Section 1101 of the Delaware Limited Liability Company Law, will make the point: ${ }^{39}$

"(c) It is the policy of this chapter to give maximum effect to the principle of freedom of contract and to the enforceability of partnership agreements. "(d) To the extent that, at law or in equity, a partner has duties (including fiduciary duties) and liabilities relating thereto to a limited partnership or to another partner, (1) any such partner acting under a partnership agreement shall not be liable to the limited partnership or to any such other partner for the partner's good faith reliance on the provisions of such partnership agreement, and (2) the partner's duties and liabilities may be expanded or restricted by provisions in a partnership agreement."

All in all, however, courts display an understandable reluctance to give too much weight to these statutory or contractual waivers of basic fiduciary duties, and tend to review the particular facts and context of a given transaction in case of litigation claiming a breach of a duty of loyalty and fair dealing. ${ }^{40}$ This outcome should surprise no

39. 6 Del. Code Section 17-1101. It has been upheld in litigation; see Kahn v. Icahn, 1998 WL 832629 (Del. Ch. 1998), as discussed in Larry E. Ribstein, Unincorporated Business Entities 331 (2nd ed. 2000).

40. See the overview and warnings in DeMott, "Fiduciary Preludes: Likely Issues for LLCs," 66 U. Colo. L. Rev. 1043 (1995). A good example of this conflict is the treatment of an early and exorbitant exculpatory Kansas statute - "All officers of the corporation. . shall be in the same position as any other member of the public from 
one. As mentioned above, it is an inherent feature of the common-law basis of United States jurisprudence even in this field. The further state legislatures today may go in immunizing agents - whether partners, directors, or officers - from personal liability for breaches of these duties, let alone in permitting the recharacterization of careless or disloyal behavior as sufficiently careful or loyal, the more the conflict between the Legislature as the Emperor of Rules and the Court as the Emperor of Events may come to the fore. ${ }^{41}$

the standpoint of doing business with this corporation, and shall not be restricted in any way from doing business with the corporation because of the fact [of being] an officer or director or stockholder of this corporation. [Kansas Stat. Anno. Sec. 17-6304 $(1972)]^{6}$ - in a case that persisted in subjecting a transaction to a traditional "fairness" rationale, Newton v. Hornblower, Inc., 582 Pac.2d 1136 (Kan. 1978).

41. See Coffee, supra n. 15. 